\title{
Cultivation of Teachers' Ideological and Political Quality in Colleges and Universities in the New Era*
}

\author{
Gaohe Wang \\ School of Marxism of Jinan University \\ Guangzhou, China 510632
}

\begin{abstract}
Ideological and political quality is the primary element of university teachers. It reflects the university-running nature and talents cultivation orientation, and concerns the prospect and destiny of the Party and state. The ideological and political quality of university teachers has the characteristic of development, and socialism with Chinese characteristics for a new era has given it new requirements. The position and role of ideals and convictions, moral sentiments, solid knowledge and heart of kindheartedness are fully highlighted. The four play the role of spiritual pillar, foundation, crucial guarantee and power source respectively in the ideological and political education in colleges and universities.
\end{abstract}

Keywords-new era; teachers in colleges and universities; ideological and political quality

\section{INTRODUCTION}

Ideological and political quality is the primary element of university teachers, and it directly relates to the fundamental problem that what kind of students the university should cultivate, how the university should train students, and whom the students should be fostered for. The ideological and political quality of university teachers has the characteristic of development. There are some differences in its basic connotation and cultivation methods in different periods, showing obvious stage characteristics. Socialism with Chinese characteristics has entered a new era, therefore, the new orientation, new contradiction, new mission, and new journey have given new demands to the ideological and political quality of university teachers. Accordingly, President Xi Jinping attaches great importance to the ideological and political work in colleges and universities, and makes a rich exposition on how to become a good teacher in the new era. He emphasizes the position and role of ideals and convictions, moral sentiments, solid knowledge and heart of kindheartedness, providing a powerful ideological weapon for university teachers to improve their ideological and political

*Fund project: this paper belongs to the staged achievements of "research on the problems and its solutions of seeking the greatest common divisor of the will of the people in the practice of comprehensively deepening reform" approval number: 15CKS020)of young project of national social science fund, "research on the respect and application of the ruling party for the opinion resources from the perspective of Marx's mass view" (14YJC710040 of young project of humanities \& social sciences fund of Ministry of Education, "the integration of Xi Jinping's theory of ideological and political work into the professional development of university teachers -- taking Jinan University as an example" of major program of ideological and political special project of colleges and universities of Jinan University. quality and shoulder the important tasks of shaping souls, lives and people.

\section{IDEALS AND CONVICTIONS: THE SPIRITUAL PILLAR FOR UNIVERSITY TEACHERS TO DEVELOP IDEOLOGICAL AND POLITICAL EDUCATION IN THE NEW ERA}

"A teacher can propagate the doctrine, impart professional knowledge, and resolve doubts." Compared with imparting professional knowledge and resolving doubts, propagating the doctrine occupies a more important position, and the most important part of propagating the doctrine lies in the education of ideals and convictions. This determines that the establishment of right ideals and convictions is the primary ideological and political quality of university teachers, as well as a spiritual pillar for the development of ideological and political education. President Xi Jinping emphasizes: "right ideals and convictions are the guiding star for imparting knowledge and educating people, and seeding the future. We cannot imagine that a person without correct ideals and convictions can become a good teacher." [1] In the new era university teachers must firmly establish the Marxist ideal conviction, and strengthen confidence in the path, theory, system, and culture of socialism with Chinese characteristics.

\section{A. Grasping the True Essence of Marxist Theory and} Actually Understanding and Believing in Doctrines

Throughout the development practice of higher education at home and abroad, any college and university is not a pure "ivory tower", and all of them hold a certain political standpoint and coexist with ideology. As for China, unique history, culture and national conditions determine that Marxism is the bright background of colleges and universities in China. As a key front of ideology construction, whether colleges and universities can give full of the leading role of Marxism and firmly grasp the leadership of ideological work have a direct impact on the nature of university-running and objective of talents training, which concerns the prospect and destiny of the Party and state. Since the foundation of New China, especially the reform and opening up, the colleges and universities always at the cutting edge of ideological confrontation. In the new era, hostile forces at home and abroad compete for positions, youth and hearts of the public, which is more complex and intense. The "red zone" of ideology in colleges and universities has been constantly squeezed by the "black zone" and "gray zone". President Xi Jinping requests that "we should not relax and weaken the 
ideological work even in one moment, and should firmly grasp the leadership, management and discourse power of ideological work. It cannot be ignored at any time, otherwise we will make irreparable historical mistakes". [2] However, from the inspection conducted by Central Inspection Group for some colleges and universities in 2017, many colleges and universities are not well aware of the importance of ideological work and the severe situation they face, and the ideological and political work are not in place, and some teachers' Marxism belief has been declined and shaken.

President Xi Jinping points out that: "the preacher must first understand the doctrine and believe in it". [3] Currently, some university teachers are affected by two major aspects in understanding the doctrine and believing in it. First, we are eroded by the adverse social trend of thought from the West. Neoliberalism, democratic socialism, universal value, constitutional democracy, and other social trends of thought have emerged in the field of Western society, and they are the products of Western scholars to study the problems of Western countries. Some thoughts and viewpoints have promoted the development of Western society in a certain period of time, while some theories have fallen into practical predicament. Some university teachers in China cannot dialectically analyze the western social thoughts, cannot see its hidden mysteries, take Western theories as the pattern, and have the greatest esteem for Western concept, discourse and methods. They trim the reform and development practice in China with Western value system, and become an advocator of Western ideology. It has caused a serious negative impact on students' establishment of a Marxist world outlook, Marxist philosophy of life, and Marxist values. President Xi Jinping indicates that: "some theoretical viewpoints and academic achievements can be used to illustrate the development course of some countries and nations, and they are reasonable in certain regions and historical cultures. But if we insist on applying them to each country and nation, using them to format human life, and taking this as a judge, it is ridiculous". [4] We can draw on and absorb some viewpoints in the western social thoughts that are conducive to the development of human civilization, but cannot regard them as a good recipe for the world. Second, there is a deviation in understanding the problems existing in the comprehensive deepening reform in China. As the source of the vitality for the development and progress of contemporary China, reform and opening up have always been conducted with problems. "Reform derives from problems and is deepened in the process of solving them". [5] Since 40 years' reform and opening up, China has solved a series of problems, but the new problems are produced constantly. Especially after the reform has entered a crucial stage, the problems that need to be solved are "tough nuts" to crack. The reform in new era is as complex, arduous and sensitive as it was at the early stage. In the face of the main problems in comprehensively deepening the reform, a few university teachers fail to see the determination and wisdom of the Party and the government in tackling major difficulties, make unreasonable accusations in the classroom or cyberspace, and even wrongly attribute the problem to the defects of the system, which has a destructive effect on college students' identity for socialist ideology, theory, and sensibility with Chinese characteristics.
The root of problems of these teachers' ideals and convictions is that they do not really understand the true meaning of Marxism. Compared with other "doctrines", Marxism has significant advantages. It integrates class nature, scientificity and revolutionary character, clarifies the objective laws of social development of human being, points out future direction of social development, reveals the historical subject position of the people, integrates the future and destiny of the nation, the country and the individual, and shows great strength in transforming the subjective and objective world. President Xi Jinping stresses that: "in the history of human thought, in terms of science, truth, influence and communication, there is no theory of thought that can reach the height of Marxism, and no theory that has had such a huge impact on the world as Marxism did". [6] University teachers should really study, understand, believe in and use Marxism, consciously resist the erosion of adverse social trend of thought in the West, scientifically understand the problems in the process of deepening reform in an all-round way, and firmly establish the lofty ideal of communism and common ideal for socialism with Chinese characteristics.

\section{B. Clarifying the Misunderstanding of Recognition and Earnestly Taking on the Mission of Propagating Doctrines of the Ancient Sages}

The university teachers should seize the precious time of university to spread Marxism for students, enable students to master the Marxist world outlook and methodology, and lay a scientific and ideological foundation for their lifelong growth and development. From the actual situation of ideological and political education in colleges and universities, some teachers have misunderstandings in the field of teaching lessons, which need to be clarified.

The first is that some teachers question the necessity of ideological and political education in colleges and universities. They believe that ideological and political education is the main task of primary and secondary education, and college students are adults or approaching adulthood, and their values are basically shaped. There is no need to promote special ideological and political education for students. President Xi Jinping indicates that: "the value orientation of young people determines the value orientation of the whole society in the future, and young people are in the period of formation and establishment of values. It is very important to seize the opportunities of the formation of values in this period". Facing the problems of study, emotion, career choice and interpersonal relationship, college students often have the psychological phenomenon of anxiety, confusion, loss and even depression. It is incumbent on colleges and universities to develop ideological and political education. Teachers should actively guide students to establish correct values, and enable students to make accurate judgments and choices between right and wrong, primary and secondary position, true and false things, good and evil behavior, and beauty and ugliness.

The second is that some teachers believe that ideological and political education should be a matter within the duties of the teachers who teach this lesson, and the teachers in other courses should be responsible for imparting professional knowledge in their subject, therefore, they lack of the 
consciousness to spread Marxism for students, which results in a situation that Marxism "keeps silence" in some subjects, "disappears" in some textbooks and "stays speechless" in the forum. Xi Jinping thinks that "an excellent teacher should be an integration of 'Confucian classics' and 'humanities"'. They should not only be skillful in 'teaching lessons' and 'disabusing', but also take 'propagating doctrines of the ancient sages' as their responsibilities and duties." [1] No matter which courses the teachers have taught, it is incompetent for them to teach lessons but not propagate doctrines of the ancient sages. Contemporary students are the major driving force to realize the Chinese dream in the future; therefore, every teacher is the builder for this "dream team". Teaching students in the overall process and all aspects is the basic principle of ideological and political education, and each teacher should keep their own "field of responsibility" so that they should be responsible and conscientious for their students, and form a synergistic effect.

The third is that some teachers equate ideological and political education with general knowledge imparting. Ideological and political education is different from general knowledge imparting, and it integrates knowledge communication with value education. The rationality of ideological and political education objectives does not ensure the effectiveness of educational results. Ideological and political education has a higher requirement for the education method relative to other majors. If the method of education is not appropriate, it will be counter-productive. President $\mathrm{Xi}$ Jinping makes comparison between ideological and political education and salt, and believes that "good ideological and political work should be like salt, but we cannot just eat salt. The best way is to dissolve salt in various foods to naturally absorb it". [9] Teachers should enhance the artistry and appeal of ideological and political education, and infiltrate students' hearts in a way of moistening things silently, so that college students can benefit and satisfy the results.

The fourth is that some teachers confuse academic and political issues when carrying out ideological and political education. Colleges and universities highly value the policy of a hundred flowers blooming and a hundred schools of thought contending. However, some teachers cannot correctly distinguish the academic and political issues, discuss the major decisions of the Party as academic issues, and publish opinions that are inconsistent with the requirements of the Party Central Committee. President Xi Jinping points out: "we encourage and support the emancipation of minds, and the analysis and evaluation of relevant policies and measures, but we must grasp the organic unity of steadfastness of political position and innovativeness of scientific exploration. We should neither equate exploratory academic issues with serious political issues, nor equate serious political issues with exploratory academic issues". Teachers should follow the discipline to teach, and academic exploration is not absolutely unbounded. We must not confuse political issues with academic ones, and cannot make any statement in violation of the Party's theoretical guidelines and policies under the banner of academic research.

\section{MORAL SENTIMENTS: FOUNDATION FOR UNIVERSITY TEACHERS TO DEVELOP IDEOLOGICAL AND POLITICAL EDUCATION IN THE NEW ERA}

Moral sentiment is a basis for university teachers to settle down, as well as a foundation for them to develop ideological and political education. University teachers must not only take on high ground of knowledge, but also become the benchmark of social morality. President $\mathrm{Xi}$ Jinping emphasizes that: "teachers should not only be a knowledge teller who imparts book knowledge, but become a 'respected scholar' who shapes students' character, conduct and taste". [11]As a mirror for students' moral cultivation, teachers must take the lead in carrying forward socialist morality and traditional Chinese virtues, to conduct you, conduct research, teach the lesson and cultivate the students with morality.

\section{A. Conducting Oneself with Morality, and Correctly Dealing with the Relationship Between Educational Undertakings and Fame and Wealth}

The noble teacher morality is highlighted in their love for education career, and they can remain unruffled in the face of money, fame and wealth. However, some university teachers have insufficient understanding of the nobility of their own career, and cannot properly manage the relationship between education career and money. They always are swayed by considerations of gain and loss, and have negative emotions. To be honest, on the one hand, as a profession, teacher is similar to other professions, and will encounter some conflicts of interest in the process of reform and development; on the other hand, differing from other professions, teacher is human soul engineer, and they have higher moral consciousness than other groups and can correctly view the benefits of career development. In the face of conflict of interests, teachers still remain cautious and conscientious, and devote themselves to education with full enthusiasm. President Xi Jinping indicates that: "education posts cannot be used only as a career to support the family. With the ambition to struggle for career, one can enjoy the position of teacher, and achieve good results. If you are in university but your heart is in business or in the officialdom, and cannot hold yourself in the battle of money, material desire, fame, and personality, you will not be a good teacher". [1] Teachers' attitudes and emotions can quickly infect students. If teachers generate negative emotions due to money, fame and wealth, it will cause psychological confusion for the growth of the university students. The reason why teachers are praised as the most brilliant career under the sun is mainly due to their dedication. Teachers must correctly understand and deal with immediate interest issues, enhance their sense of profession belonging, mission and honor, and reduce complaints in the face of money, fame and wealthy. They earnestly regard "educating talented and promising students in the world" as the highest pursuit of lifelong career and the greatest happiness of life, and willingly keep to the three feet platform without distractions.

\section{B. Conducting Research with Morality and Adhering to the Unity of Academic Freedom and Academic Norms}

Academic research is not only an inspection of knowledge literacy for university teachers, but also a test of their moral character. University teachers should insist on the unity of 
academic freedom and academic norms and put academic research on a solid foundation of "morality".

The first is to regard responsibility and interest as the biggest driving force for academic research. Responsibility and interest are the intrinsic motivation for teachers to engage in academic research, as well as the important condition for achieving high levels of academic achievement. At present, some colleges and universities put their research achievements in a prominent position when evaluating the performance of teachers. Professional title review, job evaluation and grants and awards are directly related to scientific achievements. This can encourage teachers to attach importance to academic research, but it is also easy to cause the problems of utilitarianism. Some teachers give priority to the degree of difficulty in the publication of academic results in their choosing research issues, rather than their own responsibilities and interests. Innovative and high-level researches tend to be long in term, difficult, and slow in taking effect, while repetitive and low-level researches are short in term, not difficult, and rapid in taking effect. Under the benefit balance between the "quantity" and "quality" in academic achievements, the "quantity" is given priority rather than "quality", therefore, they will pick up essay from other places at random to organize their paper and the quality is poor. This kind of research method is difficult to continue. Some teachers make hurry preparations before the professional title evaluation, reach the necessary word count, and interrupt or even completely "shut down" the academic research after post promotion. Xi Jinping stresses that works are not only equal to "body", but equal to "hearts". The scholars should have the spirit of persistence and insistence, enjoy the loneliness, resist the temptation, hold the bottom line and aim to engage in great and actual scholarship. [4]

The second is to adhere to academic ethics and resist academic misconduct. The problems such as plagiarizing others' research achievements, tampering with documents, fudging data, and buying and selling papers exist in different degrees in Chinese academic circles. From the cases of academic misconduct exposed in recent years, they not only involve ordinary teachers, but also individual academicians, the Changjiang Scholars, and other well-known experts. It is common that the papers of domestic scholars are rejected by internationally renowned journals, which seriously damages the reputation of the academic circles in China, and misleads the academic research of the students. Frequent academic misconducts of students is closely related to the infiltration of these bad academic styles. President Xi Jinping makes clear criticism on various academic misconducts, and demands that science researchers "establish good academic ethics, conscientiously abide by academic norms, adhere to knowledge, questioning, deliberation, discernment, and cleverness, advocate the value pursuit that 'scholars should expand the teachings', and truly unite the conducting oneself, work and learning". [4] University teachers must guide the academic atmosphere with their noble personality, create a good academic ecology, and provide an academic environment that is realistic, pragmatic, honest and trustworthy for students' growth.

\section{Teaching the Lessons with Morality and Paying Attention to the Combination of Words and Deeds}

The educational relationship between teachers and students is also a moral relationship. In the process of education, teachers should conscientiously fulfill their moral obligations and influence students' moral outlook through the combination of words and deeds.

The first is to ensure the leading position of teaching. Teaching is the most basic way to train talents in colleges and universities, as well as the most direct way to reflect the morality of teachers. However, some teachers pay insufficient attention to teaching, and even have a certain degree of resistance. It is impossible to teach the lessons with morality. This situation is not only influenced by the fact that some colleges and universities attach an importance to scientific research rather than teaching interests, but also related to the lack of teachers' morality. President Xi Jinping stresses that: "good teachers should persist in imparting knowledge and educating people. We often say that love whatever you are engaged in, and a teacher must love education work". [4]Teachers' first important task is teaching, and they should not only impart the knowledge, but also teach the virtues. To achieve this, on the one hand, colleges and universities need to constantly improve the teacher performance evaluation system, effectively increase the proportion of teaching work in the distribution of benefits, and guide the teachers to deal with the relationship between teaching and scientific research; on the other hand, teachers must continue to strengthen the cultivation of teachers' morality, enhance the sense of teaching achievement, form the spirit that "the dress takes to loosen gradually and I am more and more emaciated, No regretful plying at all, I am rather for her only distressed as I did", and consciously put teaching first among various works.

The second is that teaching should be consistent with the words and deeds. Colleges and universities are strong positions to cultivate and carry forward the socialist core value, and teachers should take the lead in becoming the firm believers, positive communicators and exemplary practitioners of the socialist core value. The three roles of believers, communicators, and practitioners are incremental and organically unified. But the three roles embodied in some teachers has presented some problems, resulting that they speak one way and think another and their actions contradict their words, and they become immoral "double-faced person". A person with high knowledge can be a teacher, and a person with high morality can set example for others. President Xi Jinping asks teachers to be talented and virtuous. He warned everyone with the mass evaluation: "people who have morality and talent can be regarded as "quality goods"; people who have morality but no talent can be regarded as "inferior-quality products"; people who neither have morality and talent can be regarded as "waste products"; people who have talent but no morality can be regarded as 'poison'." [10] In recent years, some college teachers, like drugs, have done a lot of things that violate ethics and law, such as taking and offering a bribe, playing favoritism and committing irregularities, whoring and gambling, academic corruption, infringement of students, which causes bad social influence and seriously blacken the overall image of teachers. We must adhere to the principle of 
zero tolerance to the black sheep, and clear them out of the ranks of teachers in time to maintain the purity of the teaching staff.

\section{LAYING A SOLID FOUNDATION FOR KNOWLEDGE: THE} IMPORTANT GUARANTEE OF COLLEGE TEACHERS DEVELOPING IDEOLOGICAL AND POLITICAL EDUCATION IN THE NEW ERA

Eliminating doubt and confusion is the significant function of ideological and political education in colleges and universities. It "should resolve the following questions for students: where they should put forth their strength, who they should fall in love with, how to pay attention to the things, and conduct what kind of person. Moreover, it should also timely dispose the actual bewildered things that students have faced in the learning life, social practice and even films and television programs and social consensus"[11]. The formation of students' ideological confusion usually not relies on one-side reason, but the ideological, life, professional factors intertwines. Only when teachers acquire solid knowledge can teachers shoulder the responsibility as students' healthy growers and guides. With the development of information society and shorter cycle of knowledge renewal, the ways for students to contact knowledge become diverse, which puts forward higher requirements for teachers' knowledge literacy. $\mathrm{Xi}$ Jinping points that "in the past, to give students a bowl of water, the teacher should prepare a bucket of water. But now, this requirement can not be met, and we should have a pool of water.'[1]Teachers should always keep the learning condition and store the solid knowledge.

\section{A. Improving Theoretical Attainment of Marxism}

Marxist theory is the basic skills that college teachers should master. Compared with the basic task of ideological and political education in the new era, many teachers have lack of Marx's theoretical accomplishment, and it is urgent for them to strengthen the study of Marxist theory.

The first is to learn the classical documents of Marxist theory. The classical documents are the basis and origin of Marxist theory and the concentrated reflection of the basic principles of Marxism. For the teachers of ideological and political theory class, Marxist theory is the foundation of the career survival and development. They should not only read the classic Marx literature, but also create a high level of academic achievements, and inject a source of power into the rich development of Marx theory. In the face of the requirements of the new era, some teachers of ideological and political theory course lack sufficient knowledge and can not give a panorama for Marxist theoretical system, answer the question of students' belief, and show the charm of the times of Marxism. Xi Jinping points that "some people who just read few books of Marxist classics deliver their opinion at will with sciolism, and this is an irresponsible attitude and is contrary to the spirit of science."[4] The teachers of ideological and political theory course should put in time and energy to study the classical documents of Marxist theory, fully master the knowledge system of Marxist theory, and became the theorists with profound Marxism theory accomplishment. For the teachers of non-ideological and political theory course, Marxist theory is also a basic knowledge that they should master, as well as the "truth scriptures" for students to eliminate doubt and confusion. However, some teachers of specialized courses believe that Marxism is out of date and get accustomed to "learning knowledge from the West", so that some students cannot correctly understand the development trend of the world and China. The discussion that Marxism is out of date does not stand up to be studied. Although Marxism was born in 170 years ago, practice showed that: "no matter how the times change and how science advances, Marxism still shows the great power of scientific thought, still occupying the commanding heights of truth and morality". [4] Teachers of non-ideological and political theory course also need to study the classical documents of Marxist theory. As they are still engaged in their own specialized work, their key point of learning should be stressed. Xi Jinping recommended ten volumes of Selections of Marx and Engels and five volumes of Special Selections of Lenin to the leading cadres who are difficult to be released from their regular work to study, and these books are also suitable for college teachers who not teach ideological and political theory course. Through reading the representative articles, they will understand the powerful vitality of Marxism.

The second is to learn the important works of Chinese Marxism. The important works of Chinese Marxism is a concentrated embodiment of the combination of basic principles of Marxism and the specific situation of China, and a main carrier for studying and grasping Mao Zedong Thought and the theoretical system of socialism with Chinese characteristics. With the advent of the new era, the Party Central Committee with Comrade Xi jinping as its core has scientifically examined the new situation and new challenges at home and abroad, and given a scientific answer to the major era topic that what kind of socialism with Chinese characteristics should be held on and to be developed, and how people to hold on and develop it. It has achieved significant theory innovation and formed the $\mathrm{Xi}$ Jinping thought on socialism with Chinese characteristics for a new era. At present, China's important political task is to study, publicize and implement Xi Jinping thought on socialism with Chinese characteristics for a new era. University teachers who shoulder the sacred mission of imparting knowledge and educating people must be at the forefront of all sectors of society, deeply understand the historical status, spiritual essence and rich connotation of Xi Jinping thought on socialism with Chinese characteristics for a new era, and focus on Xi Jinping thought on socialism with Chinese characteristics for a new era when resolving doubts and propagating the doctrine. Moreover, they must guide college students to understand new orientation, new contradiction, new mission and new journey, thoroughly grasp the responsibilities and missions given to them by the new era, and make students become a pioneer and aspirant in the forefront of times.

\section{B. Improving Professional Knowledge Literacy}

Higher education in China must cultivate qualified constructors and reliable successors for the socialist cause with Chinese characteristics. "Reliability" emphasizes the "morality", and the "qualification" highlights "talent". Only by forming good character and mastering professional knowledge can college students take on the responsibility of the times. At present, a new round of scientific and technological revolution 
and industrial transformation are gestating, and science and technology and innovation drive increasingly become the main force for economic and social development. The need for scientific knowledge and excellent talents in China is more urgent than ever before. The Party Central Committee and the State Council complies with the trend and put forward a major strategy to build world-class universities and world-class disciplines. President Xi Jinping points out that: "to run colleges and universities in China well and establish worldclass colleges and universities, we must firmly grasp the core point of improving the ability to cultivate talents in an allround way, and use this to promote other works in colleges and universities". [3] University teachers play the most important role in the comprehensive project of talent cultivation. To cultivate students as "talents", teachers are required to master profound professional knowledge first. Teachers with profound professional knowledge and accomplishment can not only open students' wisdom door by means of their academic attainments, but also tend to be more trusted by students and open students' minds with personality charm. There is a common phenomenon in the ideological and political education in colleges and universities, and students will contact dozens or even hundreds of teachers in the period of university. When they are confused, they will not open their minds to all the teachers, but focus on seeking guidance from one teacher. Some teachers have become the "star idols" for students' emotional pouring out, while some teachers have not accepted one student for such phenomenon. One important reason why university teachers have strong centripetal force for students is that they have abundant professional knowledge. A basic principle that teachers should follow is to receive education first. Teachers must be rigorous and studious, study hard, and work at studying with great care. They should strive to stand at the forefront of professional knowledge development, promote the development of existing disciplines, enshrinement of new disciplines, opening of new research areas, and development of new technologies with quality products, and lay a solid knowledge foundation for the cultivation of outstanding talents.

\section{HEART OF KindHEARTEDNESS: THE POWER SOURCE FOR UNIVERSITY TEACHERS TO DEVELOP IDEOLOGICAL AND POLITICAL EDUCATION IN THE NEW ERA}

Love is the soul of education and the power source of inspiring university teachers to develop ideological and political education. President $\mathrm{Xi}$ Jinping indicates that: "because of loving for education and students, many of teachers have the power to prepare a lesson in a lifetime and quietly devote themselves in the three-foot platform in a lifetime, have the courage to stand up when students are in danger, and have the courage to conquer new knowledge and new learning". [1] Different teachers may have different educational methods, but benevolence is an eternal theme in the hearts of all teachers. Teachers should use love to cultivate love, stimulate love, spread love, and sincerely close the distance between teachers and students, becoming a caring person who is respected and trusted by students.

\section{A. Respecting the Subjectivity of Students and Enhancing Their Learning Realm}

Respect is an indispensable spiritual food for the growth of students. "A good teacher should not only know how to respect the students, and make students feel confident and hold their head high, but also educate students to respect others by words and deeds of respecting students". [1]The most important thing for teachers to respect students is to respect the subjectivity of students and guide students to give full play to the subjectivity role.

The first is to guide students to clarify their responsibilities of times and stimulate their motivation. Why study? This is the first question to be answered to give full play to the subjectivity role of students, and it reflects the learning realm of a person and affects the efficiency of learning. At present, some college students pay much attention to personal factors when planning their careers, and ignore their responsibilities of the times to some extent. Xi Jinping emphasizes that: "every generation of young people has their own chance and opportunity, and must plan their lives and create history under the conditions of their own times. Young people are the most sensitive barometer of the times, and the responsibility of the times is given to the young people, and the glory of the times belongs to the young people". [7]College students are basically the post-95's generation. By 2020, when we complete the building a moderately prosperous society in all respects, they are only around 25 years old. By the middle of the century, when China becomes a modern powerful and socialist country, they just are less than 60 years old. The golden age of their lives is fully consistent with the strategic goal of "two centenary". Contemporary college students personally participate in and witness the realization process of the great dream of generations of Chinese, which is not only the good fortune for them but also shoulder the responsibilities of times. Teachers should guide students to have ideals and responsibilities, and consciously integrate their personal pursuit with the development of the cause of our Party and state, and study for the great rejuvenation of the Chinese nation.

The second is to develop inspiring education and cultivate students' ability of investigation. President Xi Jinping emphasizes that: "human society needs to impart the known field, update the old knowledge, mine the new knowledge, and explore the unknown field by means of education, so that the people can better understand the world and transform the world, and better create a better future for mankind". [25]As the highest stage of the education system, higher education should guide students to explore the unknown world on the basis of spreading the known. University teachers cannot directly give away free truth to students, but should enhance the inspiration of education, guide students to discover the truth, and give students a fish and also teach them to fish. The development of new media and new technologies provides good conditions for enhancing the inspiration of higher education. The teaching philosophy of flipped classroom represented by "Mooc" is absorbed by more and more teachers. Students will be encouraged to participate in the teaching in the way of discussion and dialogue, and the university classroom teaching will be promoted to transform from 
teacher-centered to student-centered, so that the subjective role of students can be better played.

The third is to strengthen the management of classroom's order and love students while be strict with them. Giving full play to the subjective role of students does not mean that teaching discipline can be ignored. Without a good teaching order, the teacher's dominance is difficult to play effectively, and the student's subjective role will be greatly reduced. However, we regret to see that some college teachers are neglecting classroom discipline management, and students are allowed to skip classes and play mobile phones in the classroom, sleep, and read books that are not related to the course. President Xi Jinping stresses: "good teachers should be full of love and trust in the education and guidance of the students. Under the premise of strict and love, the students could be sensible and emotional and 'know teachers' and 'believe their way'". [1] Teachers' strict requirements for students and maintaining good order in the classroom are not only the embodiment of the benevolent heart of teachers, but also an important guarantee for the full play of student's subjective role.

\section{B. Understanding the Difference Between Students and Treating Each Student Equally}

College students are in their youth, and they not only pay attention to individuality in clothing and apparel, but also are willing to display themselves in their studies. Teachers should understand the individuality of the students, accommodate their deficiencies, and guide them in a targeted manner, to promote students to grow together.

The first is to understand the overall differences between college students in different eras and constantly innovate educational methods. In different times, college students are faced with different opportunities, and their thinking and learning methods also undergo profound changes. Compared with previous generations of college students, "post-95" college students have two prominent characteristics: one is that they are called the "network generation". The "post-95" generation grew up in the rapid development of the Internet industry in China. Their learning mode, communication mode, thinking mode and life style are deeply branded by the Internet. The other is that they are the largest single child group. Most of the "post-95" college students are the only child in their family, and have relatively superior economic environment. Some of them have been cared by their family since childhood. On the one hand, it provides good material conditions for the growth of students, and on the other hand, it has a negative impact on the character building of some students. President $\mathrm{Xi}$ Jinping stresses that: "we should do well in ideological and political work in colleges and universities, and rise to the occasion, advance with the times and innovate according to the trend". [3]University teachers should carefully study the characteristics of the new generation of college students, follow students' growing rule, principle of teaching and educating and rules of ideological and political work, and constantly reform and innovate the educational methods, so as to encourage students to develop lifelong learning methods and habits during university.
The second is to understand the individual differences between college students in the same era and treat each one equally. College students in the same era also have different degrees of differences in academic performance, personality endowments, hobbies and interests. President Xi Jinping points out that: "good teachers should devote their warmth and emotions on every student, enhance student's confidence with appreciation, build self-esteem with trust to grow up healthily and enjoy success". [1] The main society's contradiction in the new era is highlighted by the imbalance of teachers' care for students. Teachers mostly have equal treatment of students' kindness and shall not treat them in disparity. The important reason for the different attitude of college teachers is that the teacher-student ratio is not coordinated enough. The class has more students occurs more common. It is difficult to provide in-depth understanding and targeted guidance for each student in the limited teaching time. The top priority for all colleges and universities is to adjust the teacher-student ratio structure and actively adopt small class teaching so that teachers have ample opportunity to discover the advantages and disadvantages of each student and guide them carefully. In addition, the needs of students are multi-faceted and multilayered. Students' thought confusion may occur at any time or for a long time, thus teachers should regularly communicate with students and be patient. President Xi Jinping emphasizes that the choice to be a teacher is choosing the correspond responsibility, and the teacher should embody the responsibility of the "morality nurturing" to every single thing. [12] On the one hand, strengthen the traditional way of communication between teachers and students. Traditional teachers and students' communication methods such as individual conversations and group discussions are mainly face-to-face communication and have strong affinity. However, due to the fragmentation of the school district and the teachers' own economic conditions, a large number of teachers live outside the school, and the office in the school are often full of teacher or students, which makes it difficult to communicate with teachers and students in the traditional way. Colleges and universities should continuously improve the teacher's working environment to provide necessary places for teacherstudent communication, and promote the normalization of face-to-face communication between teachers and students. On the other hand, actively use new communication channels. Teachers should actively use Internet in the principle of facilitating students, and give full play to the advantages of communication methods such as WeChat, QQ, and e-mail to timely, conveniently, and multi-directional communicate with students.

\section{CONCLUSION}

Teachers bear the historical mission of spreading knowledge, thought and truth, and shoulder the heavy responsibility of shaping soul, life and people. They are the first resource for education development, as well as an important cornerstone for national prosperity and strength, national rejuvenation and people's happiness. Socialism with Chinese characteristics has crossed the threshold into a new era. With new orientation, new journey and new mission, new higher requirements for ideological and political education in colleges and universities are put forward. To promote the 
smooth growth of college students as qualified builders and reliable successors for the cause of socialism with Chinese characteristics, we must strengthen the construction of college teachers, put the ideological and political quality of university teachers first, make them good teachers with ideals and convictions, moral sentiments, solid knowledge and heart of kindheartedness, and conscientiously assume the responsibilities of students' health instructors and moral leaders.

\section{REFERENCES}

[1] Xi Jinping. Be A Good Teacher Who Is Satisfied with the Party and the People -- Delivered at the Symposium with Teachers and Students of Beijing Normal University [N]. China Daily, 2014-09-10 (2).

[2] Excerpts from Xi Jinping's Exquisite Discussion on "Propaganda and Ideological Work" Since the 18th National Congress of the Communist Party of China [EB/OL]. Peoples Network - Communist Party of China News Network, http://cpc.people.com.cn/n/2014/0819/c16411325493994-2.html.

[3] Make Ideological and Political Work throughout the Whole Process of Education and Teaching, and Create A New Situation in the Development of Higher Education in China [N]. China Daily, 2016-1209 (1).

[4] Xi Jinping. Delivered at A Symposium on Undertakings of Social Sciences [N]. China Daily, 2016-05-19 (2)

[5] Xi Jinping. Delivered at the College of Europe in Brugge [N]. China Daily, 2014-04-02 (2).

[6] Xi Jinping Emphasized the Continued Promotion of the Chinization, Modernization and Popularization of Marxism in the 43rd Collective Study of the Political Bureau of the Central Committee of the CPC [N], People's Daily Overseas Edition, 2017-09-30 (1).

[7] Xi Jinping. Young People Should Consciously Practice the Socialist Core Values -- Delivered at the Symposium of Teachers and Students of Peking University [N]. China Daily, 2014-05-05 (2).

[8] Quoted from Commentator of the People's Daily. Continue to Use Good Approaches, Improve Old Approaches, and Explore New Approaches - Three Discussion on Studying the Conference Address of President Xi Jingping on the Ideological and Political Work of Colleges and Universities[M]. The People's Daily, 2016-12-11 (1).

[9] Xi Jinping. Delivered at the Working Conference of the National Party School [M]. Beijing: People's Publishing House, 2016: 12, 17.

[10] Quoted from Xi Jinping's First Comment on "Post-95" College Students [N]. China Daily, 2017-01-03 (2).

[11] The Launching Ceremony of the Tsinghua University Schwarzman Scholars Held in Beijing -- A Letter of Congratulations from Xi Jinping and Obama [N]. China Daily, 2013-04-22 (1).

[12] See Xi Jinping. Be A Good Teacher Who Is Satisfied with the Party and the People -- Delivered at the Symposium with Teachers and Students of Beijing Normal University [N]. China Daily, 2014-09-10 (2). 